\title{
CREATING THE IMAGE OF POLITICAL COMMUNICATORS WITH THE USE OF SOCIAL MEDIA AND COMPUTER TECHNOLOGY
}

\author{
ADAM JANKIEWICZ
}

\begin{abstract}
Nowadays, computer technology and social media can be used in certain ways to create positive or negative images of political communicators. More and more people receive political communication with the use of electronic devices via the Internet and social media. The ways in which one can create and transmit images of political communicators have evolved. Companies use new methods of gaining and delivering political information to receivers. At present, information technology is sometimes used not only to send political information but also to manipulate the receivers and change their political views in the fight for support and to win elections. Electronic devices, the Internet and social media, can be used to gain support or to defame political opponents. This paper has been written to bring closer how social media participation, computer technology and software can be utilized to obtain information which then, neatly tailored, can serve as a tool to manipulate political views of addressees of political communication. This article presents the procedure of obtaining, processing and applying information in creating images of politicians by private companies. It also analyzes people's awareness of ways in which social media communication can be used in creation of political image. Hence, a survey has been conducted to research the participation of university students in social media and their awareness of how the data obtained from them can be used in for political reasons. The paper also explains how incorporating and combining social media platforms, psychology, algorithms, the Internet and cutting edge computer software opened new ways to impact political views with political communication.
\end{abstract}

Key words: image, communication, political communicator, computer technology, social media, the Internet, data, psychological profile and personality test. 


\section{Models of communication suitable for political communication description}

Creating images of political communicators and sending them to their receivers is in accordance with the model of communication as a process published by Shannon and Weaver in 1949 and the model DRAAM (domain-resource-agent-accessmanagement) introduced by Puppel in 2004 (Shannon, Weaver, 1949; Puppel, 2004).

Table 1. Data based on: (Shannon, Weaver, 1949; Puppel, 2004)

Models of communication suitable for political communication description:

Model of communication as a process

DRAAM model (domain-resource-agent-access-management)

Shannons's model of communication as a process is a good foundation on which creating image of political communicators can be based and explained. This mathematical model describes communication as an organized event in which there are certain necessary components of the process which are also present in mass media and social media communication. They include:

- Sender - is a person who sends message via a machine,

- Channel - is the medium used to transmit message,

- Decoder - a machine which decodes signals into message,

- Receiver - is the addressee to whom message is sent.

The sender uses a code understood by the receiver to encode the message. This code can be a natural language. A technological channel is used through which the information is sent. Nowadays this channel can be a smartphone, a tv set or a computer. Then, the receiver gets the message, encodes the information and can respond to it in a particular way. This receiver's reaction is called the feedback. The process can be interrupted by the noise which is the physical disturbance that can disrupt the communication process along the way between the sender and the receiver (Shannon, Weaver, 1949).

Puppel's DRAAM model (domain-resource-agent-access-management) concerns interpersonal communication towards an ecology of human communication. It includes individual human agents in the 'agent-environment' framework that highlights their role in communication. It approaches human communication in terms of predominance of language functionalism of spoken and written language resources. The DRAAM model emphasizes that human agent communication depends on a large number of environmental (ecological) factors which influence it. Apart from that what impacts communication is the management of different communication resources by the human agent. The domain-resource-agent-access-management model 
proposes a dynamic framework of interdependencies as a proper balance between human agent's communication and the environment (Puppel, 2004).

There are certain assumptions included in the Puppel's paper entitled 'An outline of a domain-resource-agent-access-management (DRAAM) model of human communication: towards an ecology of human communication' in which the model was proposed and explained. Human agents take part in Universal Communication Space (UCS) with their potential/ability to communicate. Human agents are participants in so called Universal Social-Cultural Space and use their Human Communication Potential. Communication is contained within communicative behavior dynamics (CBD) that Human agent activates in communication act performed in communication process. Human Communication Potential is a dynamic and complex phenomenon determined by the human agent and his operational fitness. $\mathrm{Hu}-$ man agent uses Communication Resources that include language and speech resources. Communication Resources depend on the agent's knowledge of language structure and functions, time and speech production mechanism (Puppel, 2004).

\section{The procedure of using data, the internet and electronic devices in creation and transmission of political communicators' images}

Electronic devices such as smartphones, tablets and modern tv sets have the abilities that computers have and are used to transmit images of political communicators. There are certain companies that have taken part in the procedure of sending political images to viewers through electronic devices. Some of them have earned money from selling and managing computer data that was used for image creation of political communicators, such as for example: Facebook and Cambridge Analytica. Actions of the latter British company that was funded by Robert Mercer, are a matter which had an impact on the images of political candidates such as: Clinton and Trump and their voters in the United States Presidential Elections in 2016. These companies have changed the way in which image creation of political communicators can be approached. One of the ex-Directors of the British company revealed in her own words that: the largest budget is set for purchasing raw data from consumer-

Table 2. Data based on: (Jankiewicz, 2012: 28)

\begin{tabular}{|l|}
\hline \multicolumn{1}{|c|}{$\begin{array}{c}\text { Examples of electronic equipment used for transmitting images of political communicators } \\
\text { via the Internet: }\end{array}$} \\
\hline Smartphones \\
\hline Smart TV sets \\
\hline Tablets \\
\hline PC computers \\
\hline
\end{tabular}


-facing platforms like Facebook; then, the firm would acquire more specific information about its target audience through surveys and games (like personality tests) (Cao, 2018).

Whistleblower Christopher Wylie explained how 87 million records acquired from Facebook could swing the scales of 2016 United States Presidential Election. The aim was to transform surveys and Facebook data into propaganda which was called 'political messaging weapon' (Hern, 2018). The operations of influencing candidates' image perception was exposed by Wylie in the press.

Table 3. Data based on: (Hern, 2018).

\begin{tabular}{|l|}
\hline \multicolumn{1}{|c|}{ Elements needed to influence image perception were: } \\
\hline data science, \\
\hline human psychology, \\
\hline data gathering, \\
\hline building an algorithm. \\
\hline
\end{tabular}

What was needed to create this political messaging weapon were: data science, human psychology, data gathering and building an algorithm. Except for that, a few hundred thousand people were asked to fill in a 120-question personality quiz which was used to predict a person's psychological profile.

Table 4. Data based on: (Hern, 2018).

\begin{tabular}{|l|}
\hline \multicolumn{1}{|c|}{ To create a 'feature set' Facebook data gathering included: } \\
\hline the Facebook likes, \\
\hline personality tests, \\
\hline natural language text, \\
\hline and clickstream data (record of one's browsing activity). \\
\hline
\end{tabular}

Data gathering included: the Facebook likes, personality tests, natural language text and clickstream data (record of one's browsing activity).

Table 5. Data based on: (Hern, 2018).

'Five factors' model used to create psychological profile of people:

openness to experience,

conscientiousness,

extraversion,

agreeableness,

neuroticism. 
All the features were used to create a 'feature set' to make predictions on. Dr Aleksandr Kogan an academic of Cambridge University created the survey application using personality profiling which was later used to influence political views of hesitant receivers of deliberately sent political messages. A 'five factors' model was used to profile those people. These were: openness to experience, conscientiousness, extraversion, agreeableness and neuroticism (Hern, 2018). People that participated in the survey were paid from $2 \$$ to $4 \$$ but did not know that their psychological profile was created and that ones politically hesitant would later be targeted with political messages. Later, Kogan blamed the two companies for having been used as a scapegoat. Using Facebook data, the British company built tools that could influence the behaviour of American voters by identifying their personalities which was later used to send them information in order to change their political views. These techniques of so-called psychographic modelling influenced Donald Trump's campaign in 2016 (Rosenberg, Dance, 2018). After logging in on one's account and agreeing to take part in the questionnaire Facebook had access to data concerning its users without telling them. Also friends of the survey participants were directed to the psychological questionnaire by a website called Swagbucks. (Rosenberg, Dance, 2018). Harvesting data of its users was a violation of Facebook's rules at the time. Facebook executives claimed they had deleted the spying application in December 2015 and that the participants of the psychological questionnaire were told that the collected data was to be used only for academic purposes which was not true. Facebook also claimed that its users were misled by Cambridge Analytica's RussianAmerican academic Aleksandr Kogan. After US congress hearing Facebook owner was made to pay 600 thousand dollars fine over the scandal for mishandling people's information which took the company only 18 minutes to earn.

\section{The survey yes/no questions and data provided by the research participants}

Bearing in mind the deeds of the two companies a survey was conducted among university students to be used in this work. It concerned using social media platforms, the Internet and computer technology for political reasons. The study was to find out how much people knew about the way in which social media, the Internet and computer technology can be used by companies in order to influence the receivers of political messages. 92 university students were asked to fill in an anonymous survey including sixteen YES/NO questions. The participants were all adult university students of daily and extramural studies including both sexes.

The following figures present the questions and data that the participants' answers provided. The yes/no answers are given in percentages represented in numbers and graphics. 
1. Do you use social media like: Facebook, Twitter, Instagram or other?
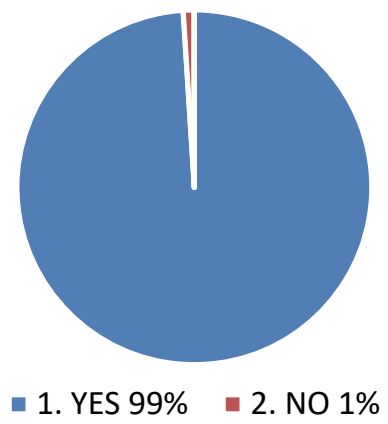

Figure 1.

2. Do you often use (e.g. a few times a week) social media like: Facebook, Twitter, Instagram or other?

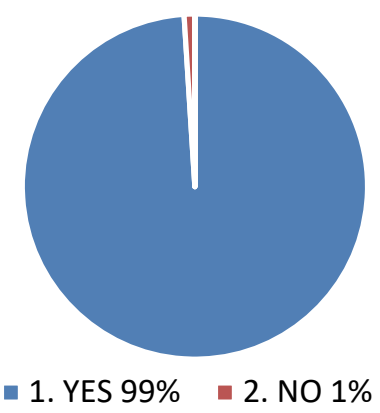

Figure 2.

3. Do you have an account in social media that you use?

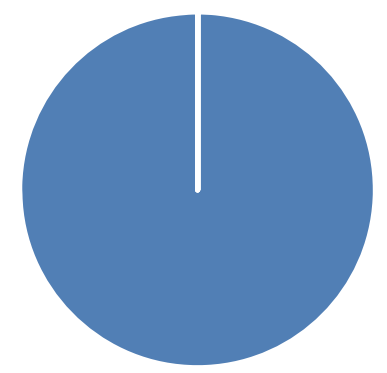

-1. YES $100 \% \quad$ - 2. NO $0 \%$

Figure 3. 
4. Do you know that the owners of social media can trade your so called 'likes' or other information concerning your visited websites without your knowledge of it?

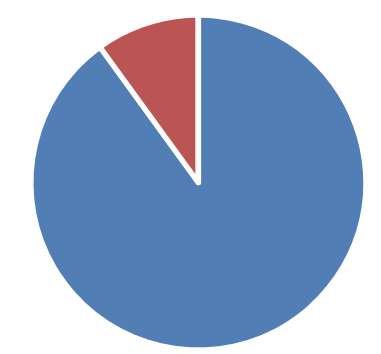

- 1. YES $90 \% \quad$ - 2. NO $10 \%$

Figure 4.

5. Would it be OK for you if social media could sell your likes or other information concerning websites that you visit to other companies without asking you for permission?

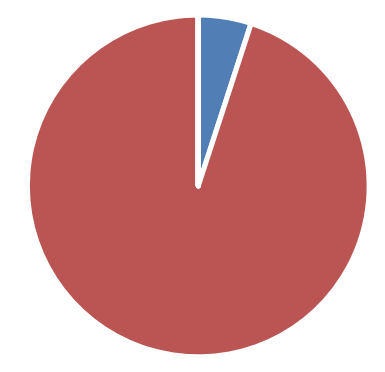

- 1. YES $5 \% \quad$ - 2. NO $95 \%$

Figure 5.

6. Are you acquainted with how your likes and other information concerning websites that you visit can be used to get financial profit via the Internet?

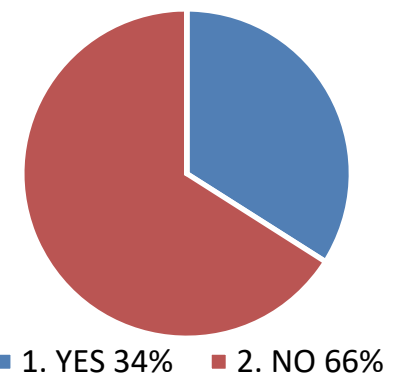

Figure 6. 
7. Are you acquainted with how your likes and other information concerning websites that you visit can be used politically via the Internet?

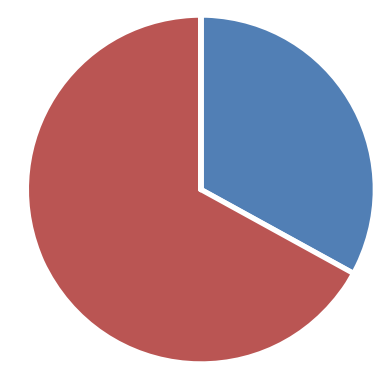

- 1. YES 33\% -2. NO $67 \%$

Figure 7.

8. Are you acquainted with the activities of Cambridge Analytica?

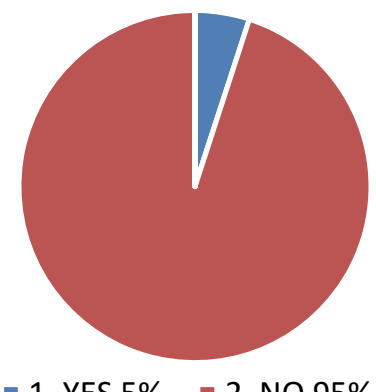

- 1. YES $5 \%$ - 2. NO $95 \%$

Figure 8.

9. Are you acquainted with how the activities of Cambridge Analytica could influence the receivers of political messages in the United States?

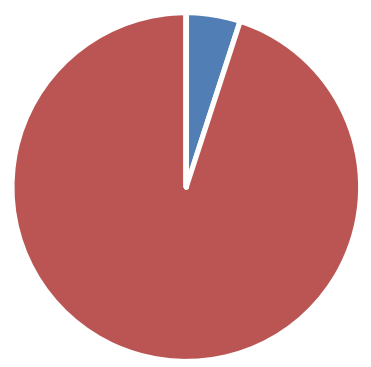

- 1. YES $5 \% \quad$ - 2. NO $95 \%$

Figure 9. 
10. Would it be appropriate for you if a company created your psychological profile without asking you for permission?

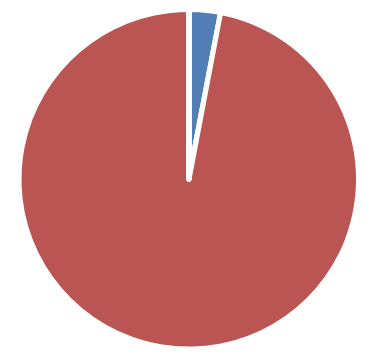

- 1. YES $3 \%=2$. NO $97 \%$

Figure 10.

11. Would it be appropriate for you if a company created a psychological profile of the members of your family without asking them for permission?

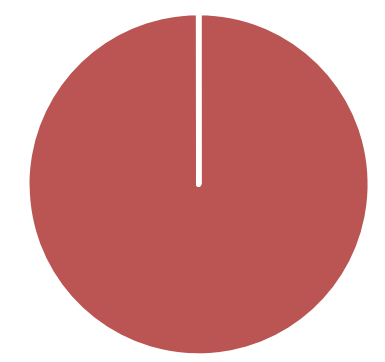

- 1. YES $0 \%-2$. NO $100 \%$

Figure 11.

12. Would you have anything against trading and earning from your psychological profile created by a company via the Internet without your knowledge of it?

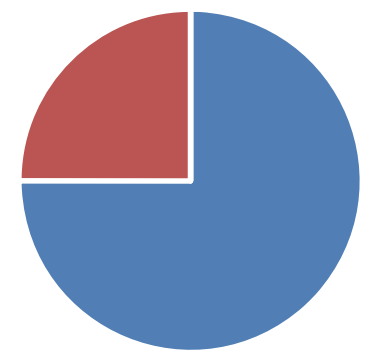

- 1. YES $75 \% \quad$ - 2. NO $25 \%$

Figure 12. 
13. Do you think that trading data of your Internet activities without your knowledge of it should be banned?

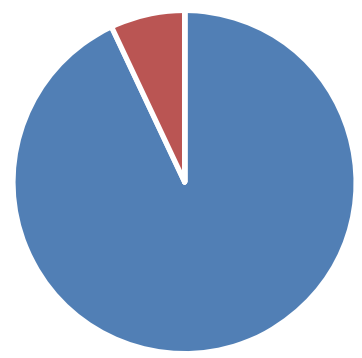

1. YES $93 \%=2$. NO $7 \%$

Figure 13.

14. Do you think that your Internet activities if legal should be protected by law as (your) intellectual property?

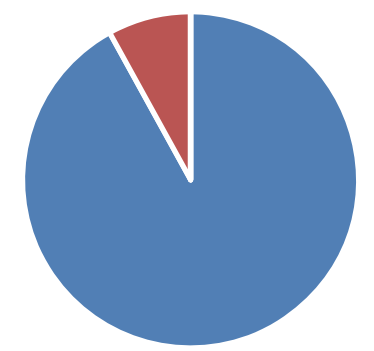

- 1. YES $92 \%=2$. NO $8 \%$

Figure 14.

15. Would you feel endangered in a way if your psychological profile was created and used as well as data of your Internet activity?

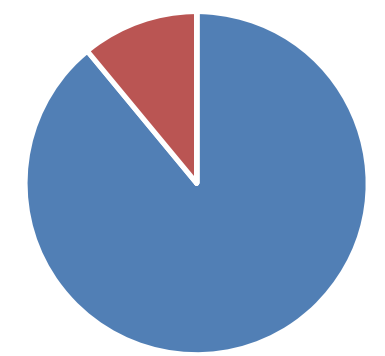

- 1. YES $89 \% \quad$ - 2. NO $11 \%$

Figure 15. 
16. Do you think that if companies created and used psychological profiles of social media participants as well as data of their Internet activity could somehow be dangerous?

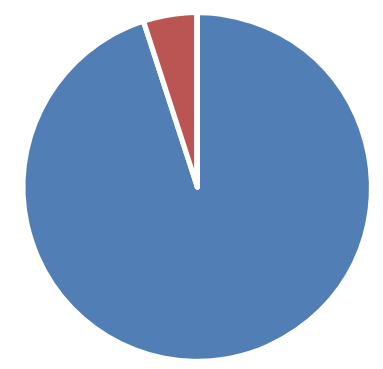

- 1. YES $95 \% \quad$ - 2 NO $5 \%$

Figure 16.

\section{Data analysis}

Majority out of 92 university students (99\%) often used social media. This means that hardly anyone does not use social media nowadays. The word which deserves emphasis here is 'often' and suggests that overwhelming majority of the people that took part in the questionnaire were willing senders and receivers of social media communication.

All the people that took part in the questionnaire had a social media account $(100 \%)$.

Only 5\% would accept social media owners to sell and use their likes and Internet activity without asking them for permission. This shows that the participants of the survey would rather be asked or at least informed about their computer data being collected, used or sold.

One in three (33\%) knew how their likes and Internet activity could be politically used.

Only 5\% knew about the activities of Cambridge Analytica and that this company could influence political messages receivers in the USA. Therefore, very few people were acquainted with or ever heard of the deeds of Cambridge Analytica.

Only $3 \%$ would accept if a company created their psychological profile without asking them for permission and none would accept $(0 \%)$ if it concerned their family members. This means that for majority of the people that took part in the questionnaire creating their psychological profile was unacceptable and that if it concerned their family totally unacceptable.

93\% agreed that trading data of their Internet activity without informing them should be banned. This reflects the questionnaire participants' disregard and rejec- 
tion of the idea of selling information concerning their Internet activity without being informed.

$92 \%$ agreed that their Internet activity should be protected by law as their intellectual property.

$89 \%$ would feel endangered if their psychological profile and Internet activity was used without their knowledge.

$95 \%$ agreed that it could somehow be dangerous if companies created and used psychological profiles of social media participants as well as data of their Internet activity. This reflects that majority of the questionnaire participants would see a threat in creating their psychological profile and using it without their knowledge.

\section{Conclusions}

Summing it up, the data collected through the questionnaire supports the view that using Information Technology for creating image of political communicators was something new for majority of the 92 research participants. Most of the people that took part in the survey were not aware of the fact that collecting, selling and profiling information gathered through spying on social media accounts could not only be traded but also used in political campaigns as it had been in United States Presidential Election in 2016. The research also proved that overwhelming majority of university students communicate through social media hence are potentially susceptible to being spied on by companies in political or economic sense. Facebook caught red handed breaking the law and its own rules with Cambridge Analytica that manipulated political views of social media communication participants opened different areas in which people's data protection rules should require new attention by researchers, the state and lawmakers.

\section{Bibliography}

Białas, B. 2011. Advergames - przyszłość polityki?. In: Jeziński, M. (ed.). Nowe Media. Vol. 2/20-11. Toruń: Uniwersytet Mikołaja Kopernika. 83-98.

Blichiewicz, S., Dunin, K., Dymek, J., Kutyła, J., Sutowski, M. and A. Wiśniewska. (eds.). 2016. Wybory USA 2016. Warszawa: Wydawnictwo Krytyki Politycznej.

Cao, S. 2018. "Ex-Cambridge analytica director unveils the dark reality of data industry". The Observer: https://observer.com/2018/04/ex-cambridge-analytica-director-speaks-out-on-facebook-scandal/, (date of access: 1.02.2019)

Cialdini, R.B. 2001. Wywieranie wpływu na ludzi. Teoria i praktyka. Gdańsk: Gdańskie Wydawnictwo Psychologiczne.

Cichosz, M. 2004. Wizerunek lidera politycznego. In: Jeziński, M. (ed.), Marketing polityczny w poszukiwaniu strategii wyborczego sukcesu. Toruń: Dom Wydawniczy DUET. 
Czaplińska, P. 2015. Strategia budowania wizerunku osób znanych. In: Grzegorczyk, A. (ed.), Perswazyjne wykorzystanie wizerunku osób znanych. Warszawa: Wyższa Szkoła Promocji, Mediów i Show Businessu.

Fleischer, M. 2002. Teoria kultury i komunikacji: systemowe i ewolucyjne podstawy. Wrocław: Dolnośląska Szkoła Wyższa Edukacji Towarzystwa Wiedzy Powszechnej.

Hern, A. 2018. "Cambridge analytica: how did it turn clicks into votes?". The Guardian: https://www. theguardian.com/news/2018/may/06/cambridge-analytica-how-turn-licks-into-votes-christopher-wylie (date of access: 1.02.2019)

Jankiewicz, A. 2012. „Cechy charakterystyczne komunikacji politycznej”. In: Puppel, S. (ed.), Scripta de Communicatione Posnaniensi IV - Transkomunikacja 2. Poznań: Wydział Neofilologii UAM. 27-38.

Jeziński, M. (red.). 2004. Marketing polityczny w poszukiwaniu strategii wyborczego sukcesu. Toruń: Dom Wydawniczy DUET.

Jeziński, M. 2011. „Po co politykom nowe media? O politycznym istnieniu w wirtualnej przestrzeni”. In: Jeziński, M. (ed.). Nowe Media. Vol. 2/ 2011. Toruń: Wydawnictwo Adam Marszałek. 11-30.

Jung, B. (red.). 2001. Media komunikacja biznes elektroniczny. Warszawa: Difin.

Kunczik, M. and A. Zipfel. 2000. Wprowadzenie do nauki o dziennikarstwie i komunikowaniu. Warszawa: Wydawnictwo Naukowe Scholar.

Labocha, J. 2008. Tekst, wypowiedź, dyskurs w procesie komunikacji językowej. Kraków: Wydawnictwo Uniwersytetu Jagiellońskiego.

Lasswell, H.D. 1948. "The structure and function of communication in society". In: Bryson, L. (ed.). The communication of ideas. New York: Institute for Religious Studies.

Leszczuk-Fiedziukiewicz, A. 2011. "Internet jako narzędzie kreowania wizerunku polityka". In: Jeziński, M. (ed.), Nowe Media. Vol. 2/2011. Toruń: Wydawnictwo Adam Marszałek.

Mcnair, B. 1998. Wprowadzenie do komunikowania politycznego. Wrocław: Wydawnictwo Alta 2.

Młynarska, K. 2011. „Zarządzanie wizerunkiem. Proces kreowania wizerunku”. In: Szplit, A. (ed.), Studia i materiaty - Miscellanea Oeconomicae. Kielce: Wydział Zarządzania i Administracji Uniwersytetu Humanistyczno - Przyrodniczego Jana Kochanowskiego w Kielcach. 20-1.

Molenda-Zdziech, M. 2001. „Socjologiczna problematyka komunikowania masowego”. In: Jung, B. (ed.), Media komunikacja biznes elektroniczny. Warszawa: Difin.

Morreale, S.P., Spitzberg, B.H., and J.K. Barge. 2008. Komunikacja między ludźmi. Warszawa: Wydawnictwo Naukowe PWN.

Puppel, S. 2004. "An outline of a domain-resource-agent-access-management (DRAAM) model of human communication: towards an ecology of human communication". Oikeios Logos 1. 2-27.

Puppel, S. (ed.), 2012. Transkomunikacja II. Poznań: Katedra Ekokomunikacji UAM.

Puppel, S. 2016. „Kuźnia Hefajstosa czyli krótki zarys teorii wizerunku w komunikacji ludzkiej”. Scripta Neophilologica Posnaniensia XVI. 109-124.

Puppel, S. 2017. (ed.), Scripta Neophilologica Posnaniensia - Prace i dnie. XVII.

Rosenberg, M., and G. Dance. 2018. "'You are the product': targeted by Cambridge analytica on Facebook". The New York Times: https://www.nytimes.com/2018/04/08/us/facebook-users-data-harves ted-cambridge-analytica.html, (date of access: 1.02.2019)

Shannon, C. and W. Weaver. 1949. A mathematical model of communication. Urbana, Ill.: University of Illinois Press. 